\title{
Analysis of electromagnetic absorption in new design of PIFA antenna using metamaterials
}

\section{Hamza Ben Hamadi}

Universite de Tunis El Manar Faculte des Sciences de Tunis

said ghnimi ( $\nabla$ said.ghnimi@gmail.com )

sciences faculty of Tunis https://orcid.org/0000-0002-6236-8711

\section{Lassaad Latrach}

Universite de Tunis El Manar Faculte des Sciences de Tunis

\section{Philippe Benech}

Université de Grenoble I: Universite Grenoble Alpes

\section{Ali Gharsallah \\ Universite de Tunis El Manar Faculte des Sciences de Tunis}

\section{Research Article}

Keywords: PIFA antenna, artificial magnetic conductor (AMC), dual-band antenna, CST simulator

Posted Date: March 24th, 2021

DOI: https://doi.org/10.21203/rs.3.rs-209779/v1

License: (9) This work is licensed under a Creative Commons Attribution 4.0 International License. Read Full License

Version of Record: A version of this preprint was published at Wireless Personal Communications on November 29th, 2021. See the published version at https://doi.org/10.1007/s11277-021-09409-9. 


\section{Abstract}

This paper presents the design, simulation and fabrication of a miniaturized wearable dual-band antenna on a semi-flex substrate; she is operable at $2.45 / 5.8 \mathrm{GHz}$ for wireless local area network applications. The electrical and radiation characteristics of this proposed antenna were obtained by means of a technical of insertion of a slot to tune the operating frequencies. To study the impact of the electromagnetic radiation of the structure of the human body, it is necessary to minimize the back radiation towards the user. Therefore, in this work, a multi-band artificial magnetic conductor (AMC) was placed directly above a dual-band planar inverted $\mathrm{F}$ antenna to achieve a miniaturization with excellent radiation performance. The simulation results were designed and simulated using Studio commercial software (CST). A good agreement was achieved between the results of simulation and the experimental. The Comparison of measurement results indicates that the gain improved from $1,84 \mathrm{~dB}$ to $3,8 \mathrm{~dB}$, in the lower band, and from $2,4 \mathrm{~dB}$ to 4,1 in the upper band, when the antenna is backed by the AMC plane. The front-to-back ratio of the AMC backed PIFA antenna was also enhanced. Then, to ensure that the proposed AMC is harmless to the human body, this prototype was placed on three-layer human tissue cubic model. It was observed that the through inclusion of plane AMC, the peak specific absorption rate (SAR) decreased to 1,45 and 1,1 $\mathrm{W} / \mathrm{kg}$ at 2,45 and $5.8 \mathrm{GHz}$, respectively (a reduction of around $3,7 \mathrm{~W} / \mathrm{kg}$, compared with an antenna without (AMC).

\section{Introduction}

Small Electric Antennas (SEA) has been intensively studied in recent years. Indeed, the antenna is an essential element used in communication system and its miniaturization plays important role in reducing the overall size of wireless communicating objects. PIFA Antenna and Microstrip Antenna (MSA) have been commonly utilized to handle wireless communication because they have low profile geometry instead of protruding as most antennas do on handheld radios. PIFA antenna is a quarter wavelength shorted patch. It consists of a ground plane, a top radiator, a coaxial probe and a short circuit linking the patch to the ground plane. Various techniques, such as strategically shaping the parasitic patch element near radiating patch, judiciously locating loads [1], adjusting the parameters of the ground plane and the short-circuit and improving the feeding scheme, can be used to optimize these antennas by adding new parameters in their design [2], [3]. The disadvantage of many low-profile antenna narrow bandwidths is always limited by impedance matching. The use of the PIFA antenna with only one single resonant mode and huge size aims at expanding the impedance bandwidth to cover a WLAN band and achieving a lowprofile structure [4],[5]. In addition, the design of the antenna must take into account the effects of the interaction with the human body to select the best design and location of the structure in wireless devices such as cellular telephones, cameras, watches, shoes, etc.

One of the most challenging tasks in the communication system is to provide the continuous interconnection of everything, everywhere with minimal power requirements. It is assumed that in the future, the number of interconnected devices will evolve with the human body. In [6], the implementation 
of an antenna was schematized, by a cyclical process, in four steps: design, antenna analysis, human interaction study and, finally, meeting the desired electromagnetic parameters.

However, PIFA antennas have the potential to provide high gain and high radiation efficiency through easy integration into mobile devices. Of this fact, PIFA antenna backed by the reflector plane, can be a good solution to improve the radiation performance and protect the body from back radiation. A planar dual-polarized antenna fabricated on a Rogers substrate, covering two frequency bands (GNSS and WLAN), was placed on multi-band artificial magnetic conductor (AMC) analyzed and studied in [7]. The AMC backed monopole antenna enhanced the radiation performance in terms of gain and FBR. In the GNSS and WLAN frequency bands, the front-to-back ratio is increased from $11 \mathrm{~dB}$ to $21.88 \mathrm{~dB}$ and $2.5 \mathrm{~dB}$ to $24.5 \mathrm{~dB}$, and the SAR is reduced to $89.45 \%$. Besides, in [9], a compact conformal antenna was backed by anisotropic meta-surface for operation at $2.45 \mathrm{GHz}$, accomplishing a gain of $6.2 \mathrm{dBi}$, a $5.5 \%$ impedance bandwidth, a front-to-back ratio greater than $23 \mathrm{~dB}$ and a $95.3 \%$ reduction in the specific absorption rate. To provide a high degree of isolation between the antenna and human body, AMC ground planes were utilized in [10] and [11,12], while maintaining a reasonably small profile. Subsequently, a multi-band antenna integrated into military beret was proposed in [13]. The developed structure worked with outstanding performance in different wearing positions on the head for indoor/outdoor positioning system. In [14], it was shown that the use of a slotted-patch antenna recessed on mushroom-shaped structure, with the feed complexity of the design on the rigid substrate, in wearable devices is a hard task.

In this paper, we have proposed and realize a dual-band antenna for wireless local area network applications. The design procedure, as well as the analysis of the characteristics of the AMC aircraft and the antenna is presented. The radiation mechanisms are identified through the measurements of the far field pattern in the anechoic chamber, revealing that the AMC plane functions not only as a reflecting ground plane, but also as the secondary radiator.

This paper is organized as follows: In the next section, we describe the design of the proposed antenna on the basis of an appropriate parametric study. Afterwards, in Section 3, the results of simulation and experimental of the antenna, the integration of the meta-surface designed to reduce its back radiation are presented. In section 4, the performance of the antenna near the human body is shown with the objective to minimize the SAR value of the two operational frequency bands. Finally, Section 5 presents a summary of all the results obtained and provides some suggestions for future research.

\section{Antenna Design}

The developed structure consists of a dual band PIFA antenna supported by a AMC network (4 rows * 4 columns). The adopted methodology is based on the design of the antenna and the AMC cell on the required frequency. For the sake of having an adjustable structure, we realized the PIFA antenna using FR4 as substrate having the following characteristics: thickness $T=1.6 \mathrm{~mm}$, relative permittivity $\mathbb{V}_{\mathrm{r}}=4.4$, relative permeability $\mu_{r}=1$ and tangential loss $\tan \delta=0.02$ (constant adjustment). 
As shown in Figure.2, the basic PIFA consists of a radiating plate, quarter wavelength (区/4), a short circuit plate and a supply wire connected to the resonating plate. Although PIFA antennas have many advantages over conventional antennas, they have the limitations of the narrow bandwidth [15].

The equivalent circuit of the proposed PIFA antenna is shown below in Figure 3. The shorting pin introduces a parallel inductance to the antenna impedance which basically shifts the resonant frequency of the antenna.

\subsection{Parametic study}

Several parameters must be taken into account when designing PIFA antennas. We began by designing a conventional PIFA $\left(L_{p} \times W_{P}\right)$ without any slots to operate at $2.4 \mathrm{GHz}$ band. The dimension of the proposed PIFA antenna is $50 * 50 * 6,4 \mathrm{~mm} 3$, he was fabricated on FR4 substrate with a thickness of 1.6 $\mathrm{mm}$ and fed by a $50 \mathrm{Ohm}$ coaxial probe.

To disturb the current path, a rectangular open-ended slot with dimensions $L_{f} \times W_{f}$ was added on the patch. The latter created obstacle and circulated the input current around it, generating the second band [16].

The optimized dimensions of the antenna, simulated and analyzed with the aid of the commercially available simulation CST Microwave Studio (CST MWS), are given in Table 1.

Table1. Antenna dimensions

\begin{tabular}{|c|c|c|c|}
\hline Parameter & Value $(\mathrm{mm})$ & Parameter & Value $(\mathrm{mm})$ \\
\hline $\mathrm{L}$ & 50 & $\mathrm{~T}$ & 1.6 \\
\hline $\mathrm{W}$ & 50 & $\mathrm{~L}_{\mathrm{f}}$ & 10,5 \\
\hline $\mathrm{L}_{\mathrm{p}}$ & 24 & $\mathrm{~W}_{\mathrm{f}}$ & 2 \\
\hline $\mathrm{W}_{\mathrm{p}}$ & 24 & $\mathrm{~W}_{\mathrm{c} 1}$ & 9 \\
\hline $\mathrm{H}$ & 6,4 & $\mathrm{~W}_{\mathrm{c} 2}$ & 7 \\
\hline
\end{tabular}

The resonant frequencies are approximated applying equation (1) of the electrical lengths.

$$
\begin{aligned}
& f_{r 1}=\frac{C}{\left(\mathrm{~L}_{\mathrm{p}}+\mathrm{W}_{\mathrm{p}}+H+T\right) * \sqrt{\varepsilon_{\mathrm{r}}}} \\
& f_{r 2}=\frac{C}{2 *\left(\mathrm{~L}_{\mathrm{f}}+\mathrm{W}_{\mathrm{f}}\right) * \sqrt{\varepsilon_{\mathrm{r}}}}
\end{aligned}
$$

where $\triangle r$ is the permeability of the used substrate and $C$ denotes the speed of light in free space. To study precise estimation, various methods were introduced and several equations were applied. In fact, in [17], the two frequencies $\mathrm{f} 1$ and $\mathrm{f} 2$ were calculated using the relations: 


$$
\begin{gathered}
L+H=\frac{4 * f_{x}}{C} \\
L+W+H-\mathrm{W}_{\mathrm{s}}=\frac{4 * f_{x}}{C}
\end{gathered}
$$

Moreover, in [18], a nonlinear fit of the least squares data, obtained using the Gauss-Newton technique, shows the good adaptation of the PIFA antenna modelization.

\subsection{Full-Wave Simulation Setup}

An AMC cell, based on square patches, was analytically modeled by an LC circuit [19]; whereas LC modeling did not include substrate losses. In the case of AMC, the equivalent electrical schematic of a AMC cell is a parallel RLC circuit [8], where R corresponds to the losses in the substrate, while $\mathrm{C}$ and $\mathrm{L}$ represent respectively-the capacity between the cells and the inductance created by the height of the substrate.

A full-wave simulation was carried out to calculate the relative dimensions and the operating bandwidth of the artificial magnetic conductor AMC.

The structure unit cell, excited by a source of an incident plane wave descend from the top of the box, was placed in a boundary conditions box (two faces of Perfect Electric Conductor (PEC) and two others of Perfect Magnetic Conductor (PMC)) to assure an infinite periodic structure.

The distance separating the upper face and the FSS surface should exceed $\lambda$ / 4 and deembedded to provide the right TEM incident's phase reference.

\subsection{Cellule unitaire CMA}

The characterization of an infinite AMC using CST Microwave Studio ${ }^{\circledR}$ can be obtained using the frequency or time solver. The resonance frequency of the AMC surface corresponds to $0^{\circ}$ of the reflection coefficient phase which allowed obtaining the operating bands.

The fundamental structure of the unit cell was manufactured on a dielectric substrate (FR4) with thickness $(\mathrm{h}=3.2 \mathrm{~mm})$. The square patch of size $17 * 17 \mathrm{~mm} 2$ resonates at $2.42 \mathrm{GHz}$, with $19.2 \%$ bandwidth over +90 reflection phase. By introducing the cross shaped slot in the patch, AMC resonated at additional resonance at $5.8 \mathrm{GHz}$ band. The $\mathrm{AMC}+90$ reflection phase bandwidth for the two required frequency bands $(2.33-2.63$ and $5.55-5.18 \mathrm{GHz})$ are represented in Figure. 8.

In the experiments carried out, a semi-rigid substrate was used because it has increased thermal and mechanical stability, which would be restricted when placed close to the human body. 


\begin{tabular}{|c|c|}
\hline Parameter & Value (mm) \\
\hline $\mathrm{L}$ & 17 \\
\hline $\mathrm{H}$ & 16 \\
\hline $\mathrm{K}$ & 5 \\
\hline $\mathrm{W}$ & 12 \\
\hline
\end{tabular}

\section{Results And Discussion}

\subsection{Electrical and radiation charactristics of the proposed antenna}

Initially, the optimized antenna without the incorporation of AMC was manufactured and tested in free space. The measured reflection coefficient showed two distinct resonant bands ranging from 2,34 to 2,57 $\mathrm{GHz}(9,2 \%)$, for Wifi/Bluetooth, and from 5,65 to $6,37 \mathrm{GHz}(12,4 \%)$ for WLAN frequencies, which corresponds well to the simulation results illustrated in Figure.10.

In order to evaluate the radiation performance of the proposed antenna, a series of measurements were carried out in the anechoic chamber (Figure.11).

The radiation patterns measured and simulated at 2,5 and 5,8 GHz on the yz (E plane) and xz (H plane) axes were compared with those of the antenna supported by the AMC plane.

According to the results, we found in figure 12, there is a good agreement between the simulation result and the measurement.

\subsection{Integration of dual-band PIFA antenna and AMC}

The unit cell was arranged into a $4 \times 4$ array to form the AMC plane, employed as the backplane of the antenna. The size of the entire dual-frequency AMC array is $68 \times 68 \mathrm{~mm} 2$, As shown in Figure 4. It consists of only eight units, each of which has a size of $17 \times 17 \mathrm{~mm} 2$. The goal of this work is to minimize the coupling of the proposed antenna with the human body.

Then, cross-shaped slots were introduced into the square patch. Compared with the conventional square unit cell designed on the same substrate, it not only introduces dual-band behavior, but also helps to miniaturize the cell by $32 \%$. Furthermore, both AMC plane and the proposed antenna, positioned at its center, were separated by a $2 \mathrm{~mm}$ thick foam spacer.

As shown in Figure 13, due to the manufacturing tolerances of the model, slight differences between the measurement results and the simulation results obtained for the reflection coefficient of the antenna with AMC were observed. The working range of the antenna with AMC for $-10 \mathrm{~dB}$ return loss measurement varies from 2.43 to $2.62 \mathrm{GHz}$ in Wifi/Bluetooth, and from 5.69 to $5.9 \mathrm{GHz}$ in the WLAN frequency band. 
The measurement results of the radiation performance, represented in the following Figures, show the smooth functioning of the AMC on the two frequency bands. Indeed, the radiation pattern measured in the $\mathrm{E}$ and $\mathrm{H}$ planes is then compared to the radiation pattern of the PIFA antenna supported by the AMC plane in two frequency bands when placed above the human body model.

The measured gain for the proposed antenna without $A M C$ is $3,8 \mathrm{~dB}$ and $4,1 \mathrm{~dB}$ in both frequency bands. Indeed, the use of this AMC plane allowed increasing the maximum gain by almost 1,96 and 1,7 $\mathrm{dB}$ for the two frequency bands of 2.45 and $5.8 \mathrm{GHz}$, respectively.

\section{Effect Of The Antenna On The Human Body}

The exposure of the phantom to radiation produced by PIFA antennas at frequencies $2.4 \mathrm{GHz}$ and $5.8 \mathrm{GHz}$ was modeled with the time solver of the CST MWS electromagnetic module. A three-layer cubic model of human tissue was placed $5 \mathrm{~mm}$ below the structure [20]. The thickness of each layer is shown in Figure.16.

Table.3. Electrical properties of human tissue

\begin{tabular}{|c|c|c|c|}
\hline Tissue & Frequency [GHz] & Permittivity [ $\varepsilon \mathrm{r}]$ & 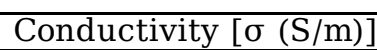 \\
\hline \multirow[t]{2}{*}{ Skin } & 2.4 & 38,06 & 1,440 \\
\hline & 5.8 & 35.11 & 3.72 \\
\hline \multirow[t]{2}{*}{ Fat } & 2.4 & 5,285 & 0,102 \\
\hline & 5.8 & 4.95 & 0.29 \\
\hline \multirow[t]{2}{*}{ Muscle } & 2.4 & 53,63 & 1,774 \\
\hline & 5.8 & 48.48 & 4.96 \\
\hline
\end{tabular}

The following Figures depict the simulation results of reflection coefficient and radiation patterns of the antenna with and without the AMC in the presence of the human body model.

The return loss shows that antenna without AMC support did not perform well in terms of adaptation and bandwidth. On the contrary, when supported by the AMC plane, the performance is significantly improved in both frequency bands while maintaining its polarization characteristics. Comparing the radiation patterns parameter of the structure only to its radiation patterns parameter when interacting with the model, we observe that the proposed AMC backing allowed protecting the human body as well as improve the performance of the antenna developed for wireless applications

On the other hand, when the proposed antenna is supported by the CMA and evaluated on the model, the FBR (Front to Back Ratio) increased from $0,3 \mathrm{~dB}$ to $16,5 \mathrm{~dB}$ and from $0,2 \mathrm{~dB}$ to $12,5 \mathrm{~dB}$ in the WIFI/Bluetooth and WLAN band, respectively.

The SAR value must be lower than the values given by the International Commission for Non-lonizing Radiation Protection (ICNIRP). On the $1 \mathrm{~g}$ and $10 \mathrm{~g}$ tissues, the SAR value shall not be greater than $1.6 \mathrm{~W} /$ $\mathrm{Kg}$ and $2 \mathrm{~W} / \mathrm{Kg}$, respectively. It is therefore essential to know the levels of the radiation absorbed by the human body. The local SAR was evaluated by determining the electric field in the phantom liquid created by the presence of an antenna near it. The SAR level is calculated and expressed as below: 
Table.4. SAR level of the prototype on the human body

\begin{tabular}{|c|c|c|c|c|c|}
\cline { 3 - 6 } \multicolumn{2}{c|}{} & \multicolumn{2}{c|}{ Antenna without AMC } & \multicolumn{2}{c|}{ Antenna with AMC } \\
\hline Unit(W/Kg) & Standard & 2,45 & 5,8 & 2,45 & 5,8 \\
\hline 1g average & 1,6 & 4,28 & 3,76 & 1,05 & 0,86 \\
& & & & & \\
\hline 10g average & 2 & 5,34 & 4,83 & 1,45 & 1,19 \\
& & & & & \\
\hline
\end{tabular}

The SAR values were simulated on the basis of the IEEE C95.1-2005 standard using an input power of $0.5 \mathrm{~W}$. The table above illustrates the simulated SAR of the proposed antenna with and without AMC plane. Indeed, due to the existence of the AMC scheme, the SAR was also reduced, from $5.3 \mathrm{~W} / \mathrm{Kg}$ to $1.45 \mathrm{~W} / \mathrm{Kg}$ in the lower frequency band, and from $4.8 \mathrm{~W} / \mathrm{Kg}$ to $1.1 \mathrm{~W} / \mathrm{Kg}$ in the upper frequency band.

Table.5. Comparison of the proposed AMC-backed PIFA antenna with some references

\begin{tabular}{|c|c|c|c|c|c|c|}
\hline $\operatorname{Ref}$ & Area $\left(\mathrm{mm}^{*}{ }^{* \mathrm{~mm}}\right)$ & Freq (GHz) & FBR, Gain & Bandwidth & $\begin{array}{l}\text { SAR } \\
\end{array}$ & Material \\
\hline [30] & $60 * 60$ & $4.5 / 4.98(\mathrm{GHz})$ & $\begin{array}{c}\text { FBR: } \\
16.2 / 15 \mathrm{~dB} \\
\text { Gain : } \\
1.87 / 1.56 \mathrm{dBi}\end{array}$ & $2.8 \% / 1 \%$ & N.A & FR4 \\
\hline [31] & $81 * 81$ & $2.45(\mathrm{GHz})$ & $\begin{array}{c}17 \\
\text { Gain : } \\
7.2 \mathrm{dBi}\end{array}$ & $14.7 \%$ & $0.55(\mathrm{~W} / \mathrm{Kg})$ & PDMS \\
\hline [32] & $50 * 50$ & $2.4(\mathrm{GHz})$ & $\begin{array}{c}\text { FBR: } \\
\text { N.A } \\
\text { Gain : } \\
1.77 \mathrm{dBi}\end{array}$ & $1.88 \%$ & $1.24(\mathrm{~W} / \mathrm{Kg})$ & latex \\
\hline [33] & 968(area) & $2.45 / 5.8(\mathrm{GHz})$ & N.A & $1.2 \% / 2.0 \%$ & N.A & Rogers Duroid \\
\hline [14] & $150 * 150$ & $1.8 / 2.45(\mathrm{GHz})$ & $\begin{array}{c}\text { FBR: } \\
\text { 15.55 / 15.64 dB } \\
\text { Gain: } \\
\text { N.A }\end{array}$ & $12.7 \% / 7.9 \%$ & $\begin{array}{c}0.024 / \\
0.016(\mathrm{~W} / \mathrm{Kg})\end{array}$ & Jean \\
\hline This work & $68 * 68$ & $2.45 / 5.8 \mathrm{GHz}$ & $\begin{array}{c}\text { FBR: } \\
\text { 16,5 / 12,5 dBi } \\
\text { Gain : } \\
\text { 3,8 / 4.1 dB }\end{array}$ & $9,2 \% / 12,4 \%$ & $1,45 / 1,1(\mathrm{~W} / \mathrm{Kg})$ & FR4 \\
\hline
\end{tabular}

Moreover, until now, no such PIFA antenna supported by AMC and designed for wireless local area network applications has been found in the literature. Nevertheless, Table 5 compares this work with antennas supported by AMC planes.

\section{Conclusions}

In this work the analysis of electromagnetic absorption in the new design of PIFA antenna with slot was carried out. This proposed antenna based on a conventional square patch and resulting a mono-band behavior, the second frequency (the dual-band) was obtained by means of the insertion of the slot on the resonant cavity of the patch. In order to optimize the antenna performance and with minimum effect of the EM fields on the human body, we used a $4 * 4$ AMC plane. The performance of the simulated antenna with and without $A M C$, placed on a three-layer cubic model of human tissue, was assessed. Then, the measured gain and radiation pattern of the PIFA antenna without AMC were compared with the performance of the antenna supported by AMC. The measurement gain of the proposed prototype is increased by $3.8 \mathrm{~dB}$ in the lower frequency band and $4.1 \mathrm{~dB}$ in the higher frequency band. Therefore, due 
to the isolation capability of the AMC plane, the SAR was reduced to a safe range $(2.0 \mathrm{~W} / \mathrm{Kg}$ over $10 \mathrm{~g}$ tissue) by $72,8 \%$ and $75,3 \%$ for $2.45 \mathrm{GHz}$ and $5.8 \mathrm{GHz}$, respectively

\section{Declarations}

*Funding: none ('the research was not funded or supported by any party')

*Conflicts of interest/Competing interests: none ('the authors have no conflicts of interest including financial interest')

*Availability of data and material: yes (I confirm the transparencies of data and material )

*Code availability ('not applicable')

*Authors' contributions (The ethics approval, the consent to participate and the consent for publication between authors (Yes, compatibility is present)

\section{References}

[1] Hamadi, B. H., Ghnimi, S., Latrach, L., Benech, P. et Gharsallah, A. (2020). NEW DESIGN OF MULTIBAND PIFA ANTENNA WITH REDUCED SAR FOR MOBILE AND WIRELESS APPLICATIONS. An international journal wireless personal communications, Vol 115, , No. 2, 2020, pp. 1211-1226.

[2] Shakib, M.N., Moghavvemi,M., \& Mahadi, W.N. L. (2015). A LOW-PROFILE PATCH ANTENNAfor ULTRAWIDEBAND APPLICATION. IEEE Antennas and Wireless Propagation Letters, vol. 14, pp. 1790-1793.

[3] Malekpoor, H., \& Jam, S. (2015). ANALYSIS ON BANDWIDTH ENHANCEMENT OF COMPACT PROBEFED PATCH ANTENNA WITH EQUIVALENT TRANSMISSION LINE MODEL. IET Microwaves, Antennas \& Propagation, vol. 9, no. 11, pp. 1136-1143.

[4] Varma, R., \& Ghosh, J. (2019). ANALYSE ET CONCEPTION D'UN PIFA COMPACT À TRIPLE BANDE MÉANDRÉ POUR WLAN 2,4/5,2/5,8 GHZ. Microwaves, Antennas and Propagation, vol. 13, no. 4, pp. 505509.

[5] Gao, G., Yang, C., Hu, B., Zhang, R., \&Wang, S. (2019). A WIDE-BANDWIDTH WEARABLE ALL-TEXTILE PIFA WITH DUAL RESONANCE MODES FOR $5 \mathrm{GHZ}$ WLAN APPLICATIONS. IEEE Transactions on Antennas and Propagation, Vol. 67, No. 6, pp. 4206- 4211.

[6] Domingo, P. V. D., \& Raidel, L. P. (2016). DESIGN OF A DUAL-BAND PIFA FOR HANDSET DEVICES AND IT SAR EVALUATION. Engineering Research and Technology, Vol. 17, No. 2, pp. 169-177.

[7] Paracha, K, N. P.,Abderahim, S. K. A., Soh, P. J., Kamarudin, M. R., Tan, K., Lo, Y. C., \& Islam, M. T. (2019). A LOW PROFILE, DUAL-BAND, DUAL POLARIZED ANTENNA FOR INDOOR/OUTDOOR WEARABLE APPLICATION. IEEE Access, Vol. 7, pp. 33277- 33288. 
[8] Linot, F., Begaut, X., Soiron, M., Renard, C., \& Labeyrie, M. (2009). CHARACTERIZATION OF A LOADED HIGH IMPEDANCE SURFACE. International Journal of Microwave and Wireless Technologies, vol. 1, no. 6, pp. 483-487.

[9] Jiang, Z. H., Brocker, D. E., Sieber, P. E. and Werner, D. H. (2014). A COMPACT, LOW-PROLE METASURFACE-ENABLED ANTENNA FOR WEARABLE MEDICAL BODY AREA NETWORK DEVICES. IEEE Transactions on Antennas and Propagation, Vol. 62, No. 8, pp. 4021-4030.

[10] Abirami, B. S., \& Sundarsingh, E. F. (2017). EBG-BACKED EXIBLE PRINTED YAGIUDA ANTENNA FOR ON-BODY COMMUNICATION. IEEE Transactions on Antennas and Propagation, Vol. 65, No. 7, pp. 37623765 .

[11] Velan, S. (2015). DUAL-BAND EBG INTEGRATED MONOPOLE ANTENNA DEPLOYING FRACTAL GEOMETRY FOR PORTABLE APPLICATIONS. IEEE Antennas and Wireless Propagation Letters, Vol. 14, pp. 249-252.

[12] Yan, S., Soh, P. J., \& Vandenbosch, G. A. E. (2014). LOW-PROLE DUAL-BAND TEXTILE ANTENNA WITH ARTICIAL MAGNETIC CONDUCTOR PLANE. IEEE Transactions on Antennas and Propagation, Vol. 62, No. 12, pp. 6487-6490.

[13] Lee, H., Tak, J. and Choi, J. (2017). WEARABLE ANTENNA INTEGRATED INTO MILITARY BERETS FOR INDOOR/OUTDOOR POSITIONING SYSTEM. IEEE Antennas and Wireless Propagation Letters, Vol. 16, pp. 1919-1922.

[14] Saurav, K., Sarkar, D., \& Srivastava, K. V. (2014). DUAL-POLARIZED DUAL-BAND PATCH ANTENNA LOADED WITH MODIED MUSHROOM UNIT CELL. IEEE Antennas and Wireless Propagation Letters, Vol. 13, pp. 1357-1360.

[15] Belhadef, Y., \& Hacene, N. B. (2011). DESIGN OF NEW MULTIBANDED SLOTTED PIFA ANTENNA. 978-1-4577-0690-5/11\$26.00 IEEE

[16] Hamadi, H., Ghnimi, S., Latrach, L., \& Gharsallah, A. (2019). ANALYSIS AND DESIGN OF A NEW PIFA ANTENNA FOR THE WIRELESS COMMUNICATION APPLICATIONS. In The 19th IEEE Mediterranean Microwave Symposium.

[17] Laheurte, J. M. (2011). COMPACT ANTENNAS FOR WIRELESS COMMUNICATIONS AND TERMINAL. Theory and Design. Wiley, pp. 153-160

[18] Chattha, H. T. (2012). A COMPREHENSIVE PARAMETRIC STUDY OF PLANAR INVERTED-F ANTENNA. Wirel. Eng. Technol, vol. 03, no. 01, pp. 1-11

[19] Pimenta, M. S. (2014). FLEXIBLE ANTENNAS BASED ON METAMATERIALS WITH ARTIFICIAL MAGNETIC CONDUCTORS FOR GEOLOCATION SYSTEM STANDARDS. University of Nice Sophia Antipolis, Nice. https://tel.archives-ouvertes.fr/tel-00923200/document. 
[20] Gao, G.P., Yang, C., Hu, B., Zhang, R. F., \& FeiWang, S. (2019). A WEARABLE PIFA WITH AN ALLTEXTILE METASURFACE FOR $5 \mathrm{GHZ}$ WBAN APPLICATIONS. IEEE antennas and wireless propagation letters, vol. 18, no. 2, pp. 288-292.

[21] Zhang, X., Teng, Z., Liu, T. Z., \& Li, B. (2015). A DUAL BAND PATCH ANTENNA WITH A PINWHEELSHAPED SLOTS EBG SUBSTRATE. International Journal Antennas Propagation, vol. 2015, pp. 1_8.

[22] Gao, G. P., Hu, B., Wang, S. F., \& Yang, C. (2018). WEARABLE CIRCULAR RING SLOT ANTENNA WITH EBG STRUCTURE FOR WIRELESS BODY AREA NETWORK, IEEE Antennas and Wireless Propagation Letters, vol. 17, pp. 434-437.

[23] Agarwal, K., Guo, Y. X., \& Salam, B. (2016). WEARABLE AMC BACKED NEAR-ENDFIRE ANTENNA FOR ON-BODY COMMUNICATIONS ON LATEX SUBSTRATE. IEEE Transactions on Components, Packaging and Manufacturing Technology, vol. 6, no. 3, pp. 346-358.

[24] Zhu, X. Q., Guo, Y. X., \& Wu, W. (2015). A COMPACT DUAL-BAND ANTENNA FOR WIRELESS BODYAREA NETWORK APPLICATIONS. IEEE Antennas and Wireless Propagation Letter, vol. 15, pp. 98-10.

\section{Figures}

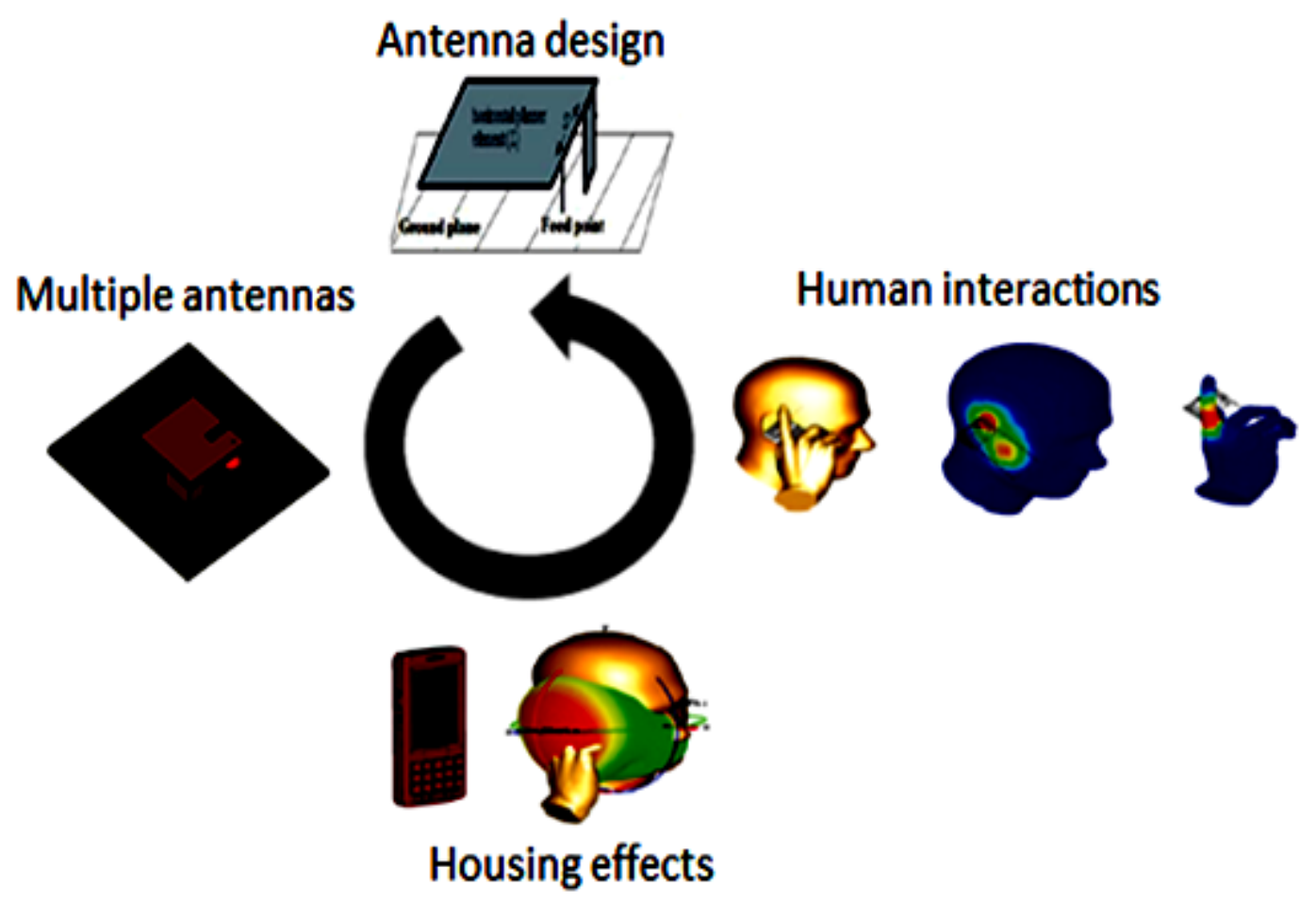

Figure 1

Schematic process for PIFA antennas implementation 


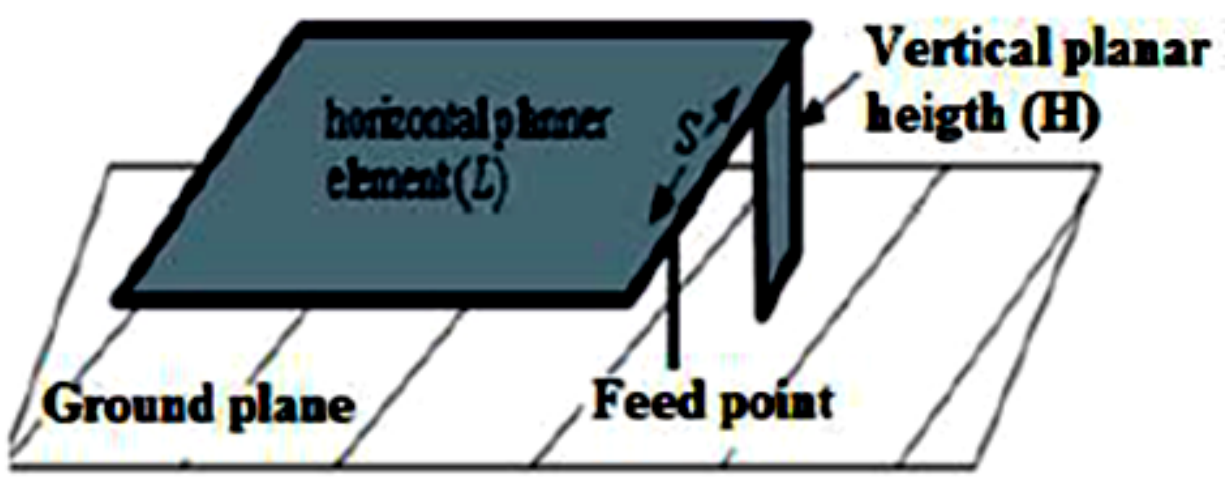

Figure 2

Planar Inverted F Antenna

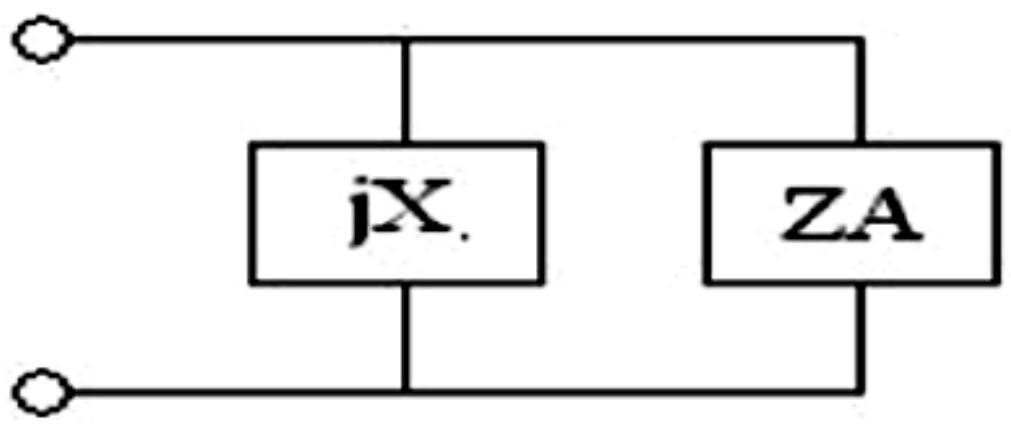

Figure 3

Equivalent circuit of PIfA antenna

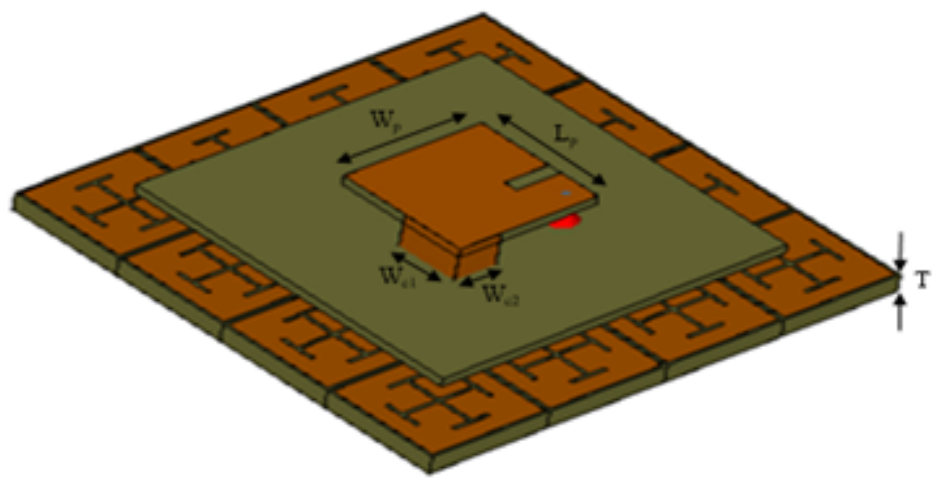

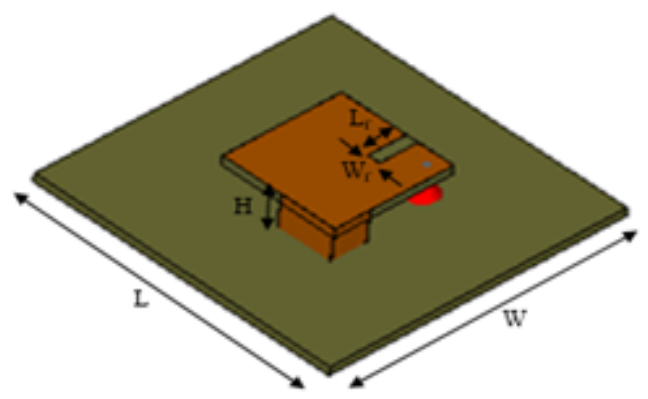

(b) (a)

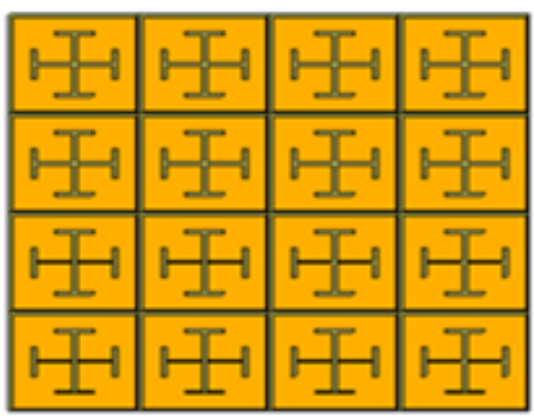

(c) 
Figure 4

(a) Configureuration of the prototype (antenna and metamaterial), (b) 3D view of PIFA antenna, (c) Top view of the AMC

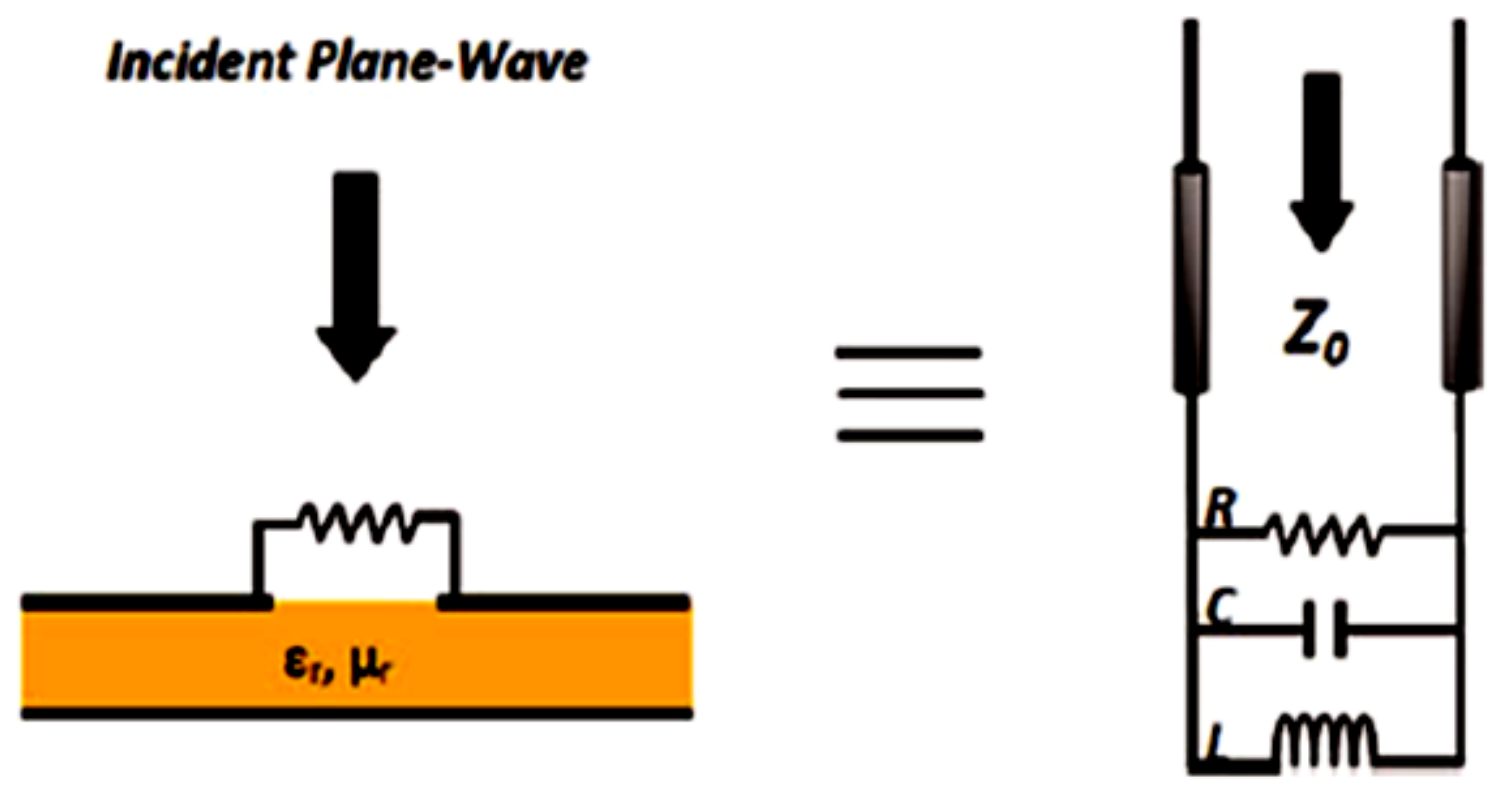

Figure 5

Electric equivalent circuit of a AMC cell

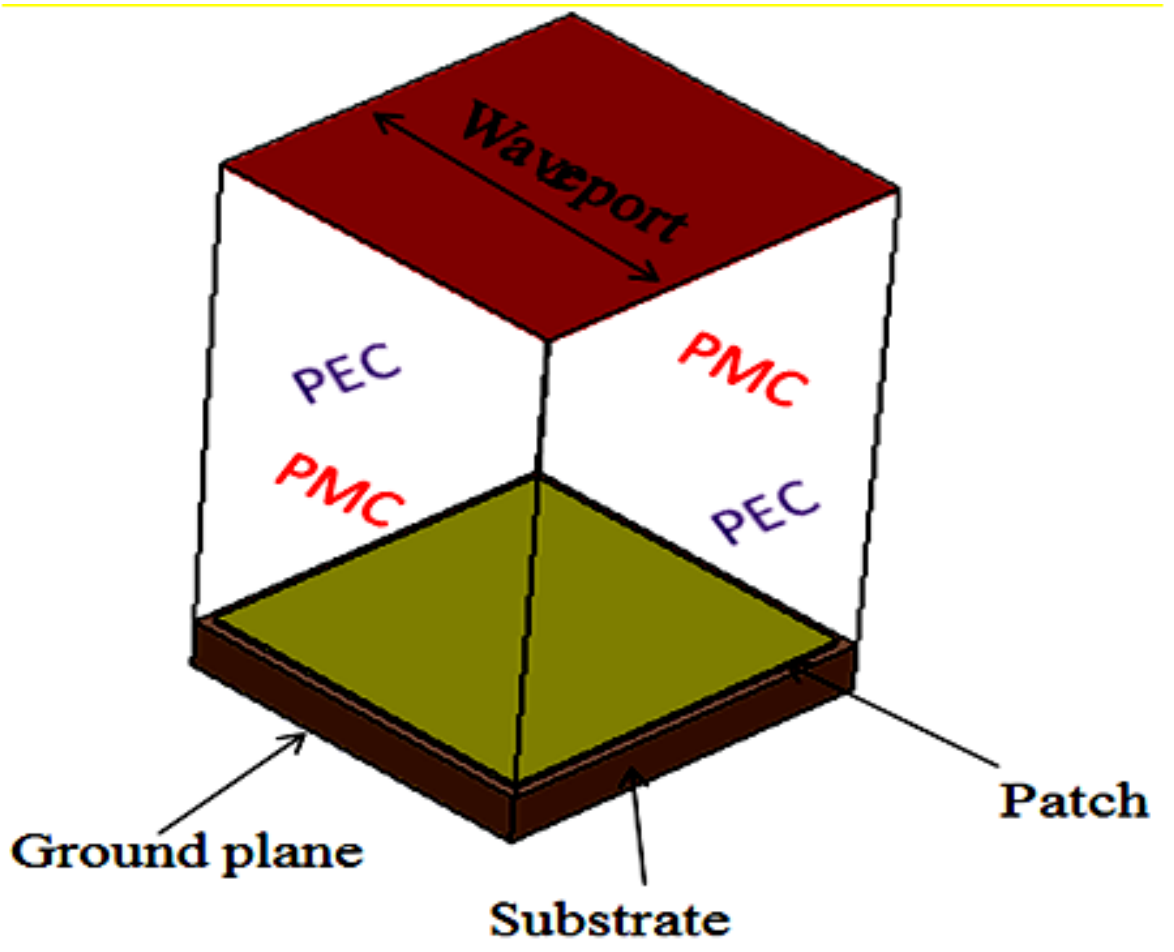

Figure 6

Unit cell simulation with boundary conditions for simple square AMC surface 


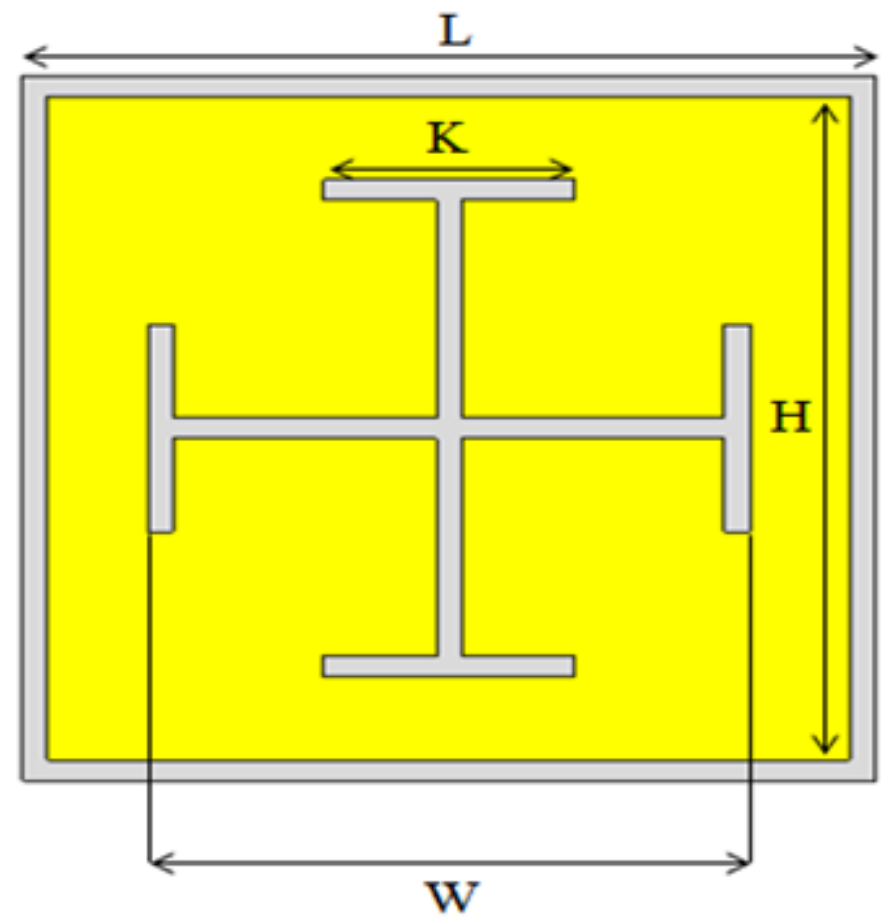

Figure 7

Unit-cell of dual-band AMC

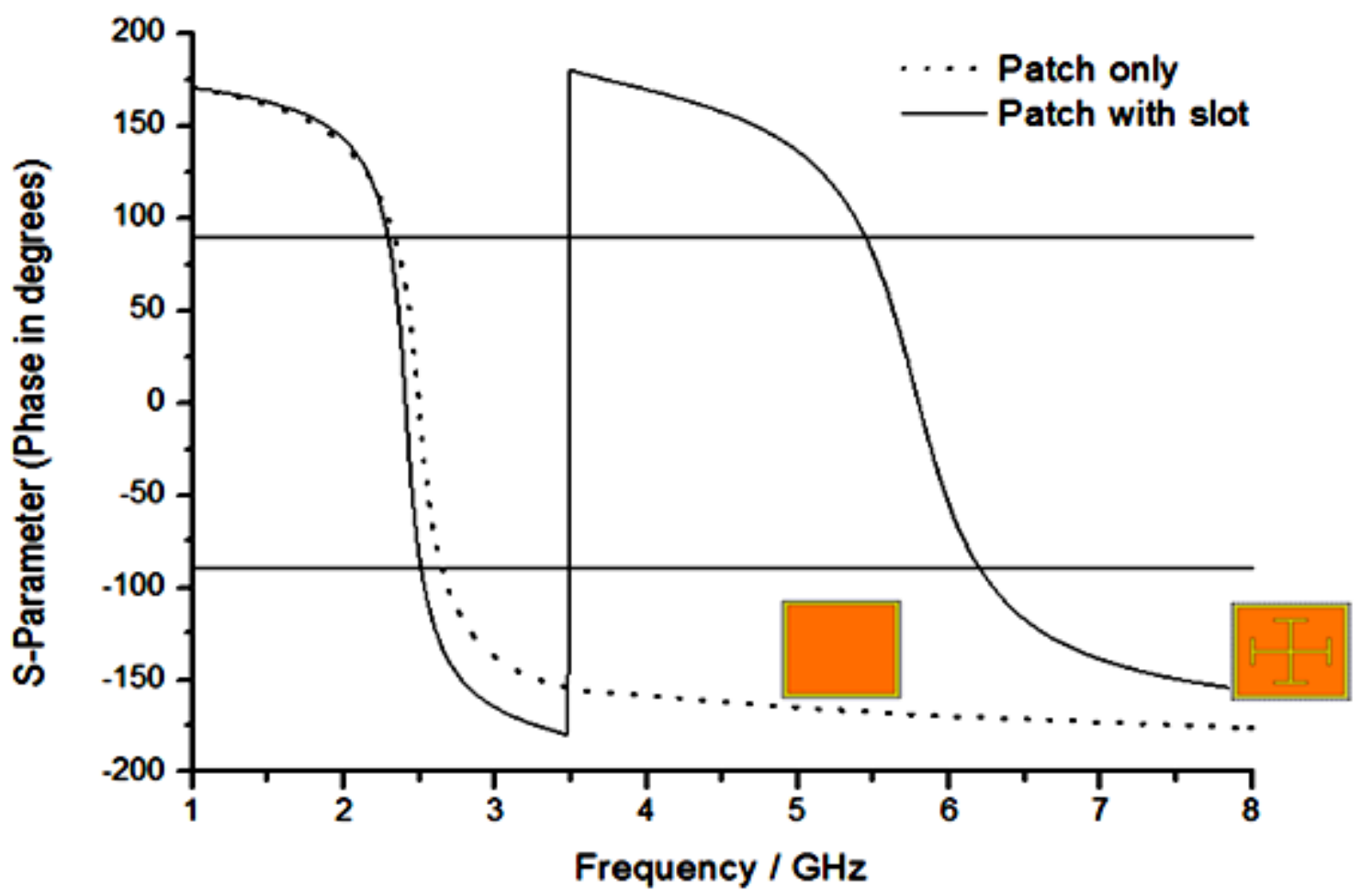

Figure 8

Simulated reflection coefficient for simple square and Jerusalem cross AMC structures 

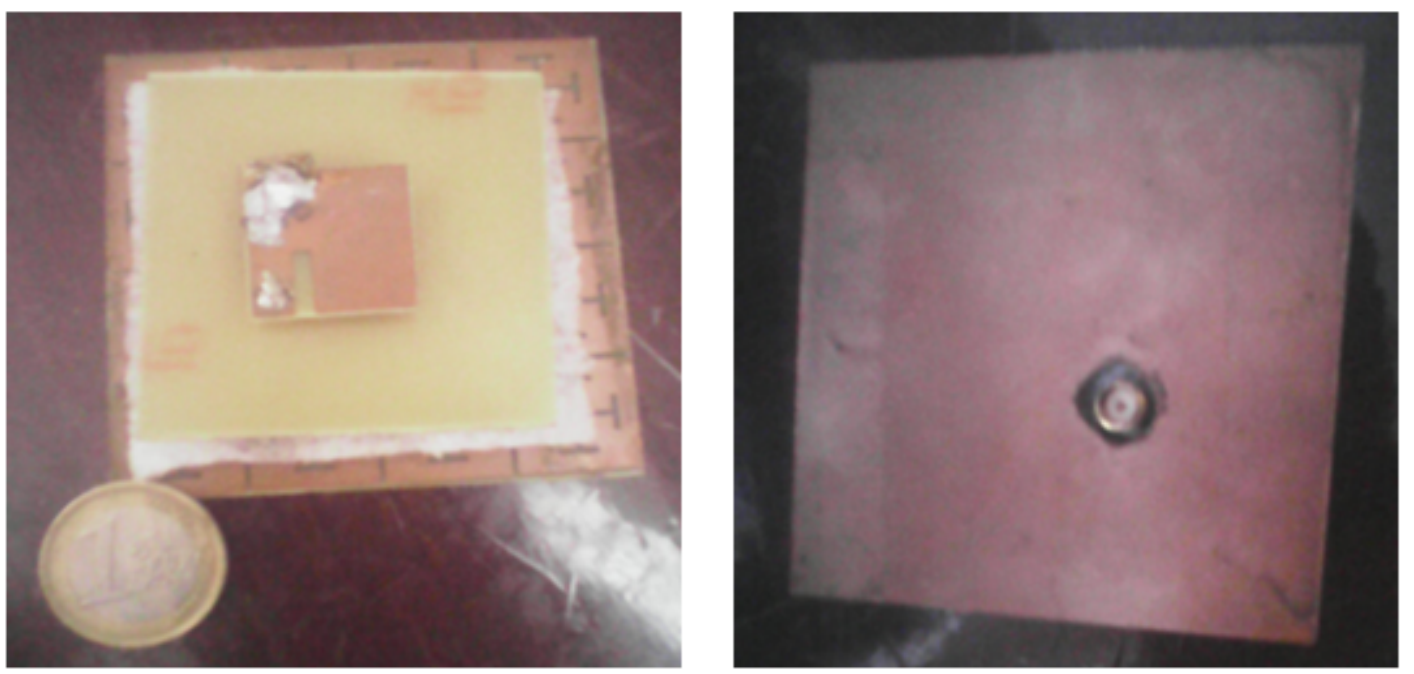

Figure 9

(a) Top view of the fabricated Prototype (AMC backed antenna), (b) Bottom view of the whole structure

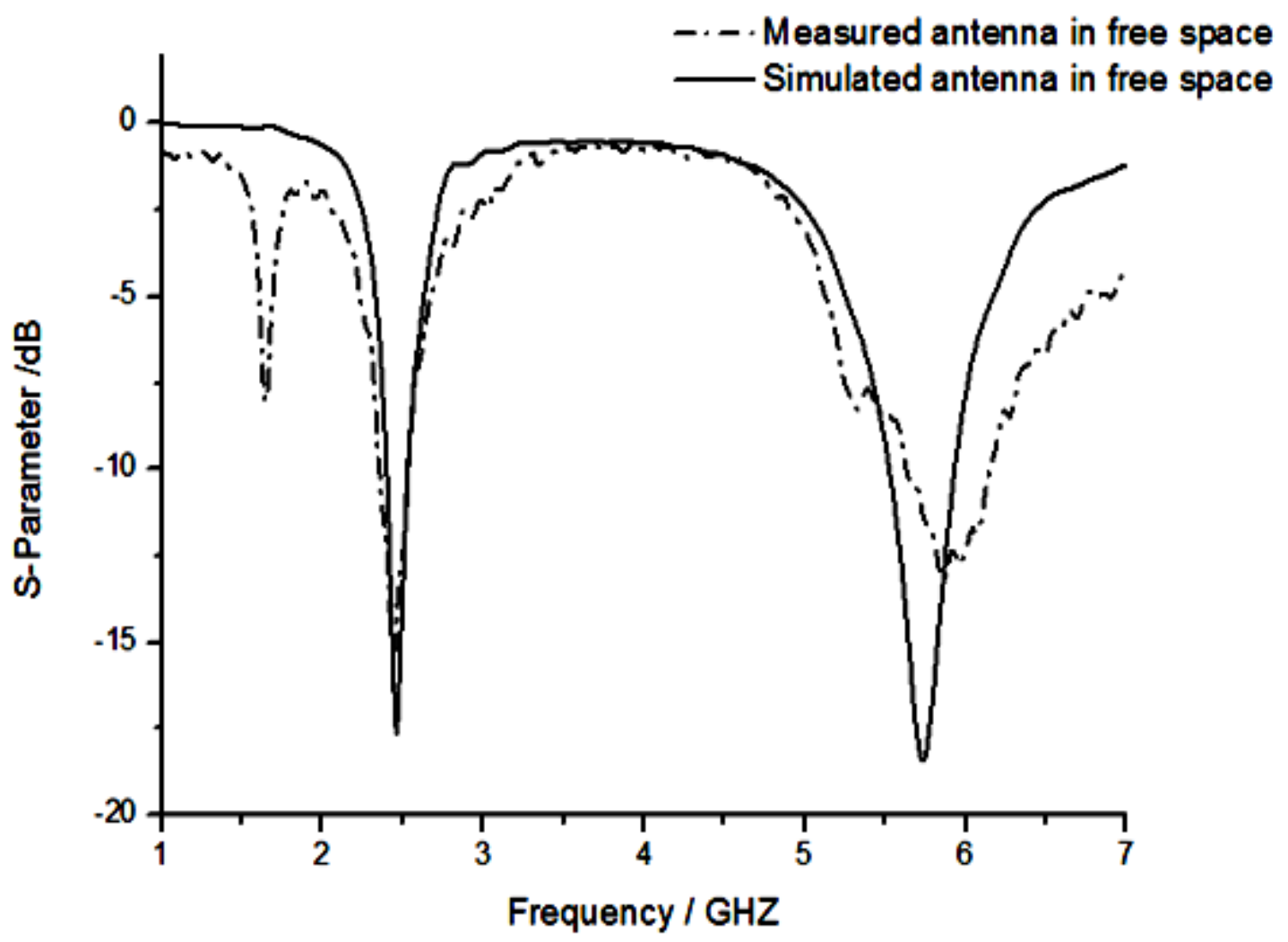

Figure 10

Simulated and measured S11 of the antenna in Free space 

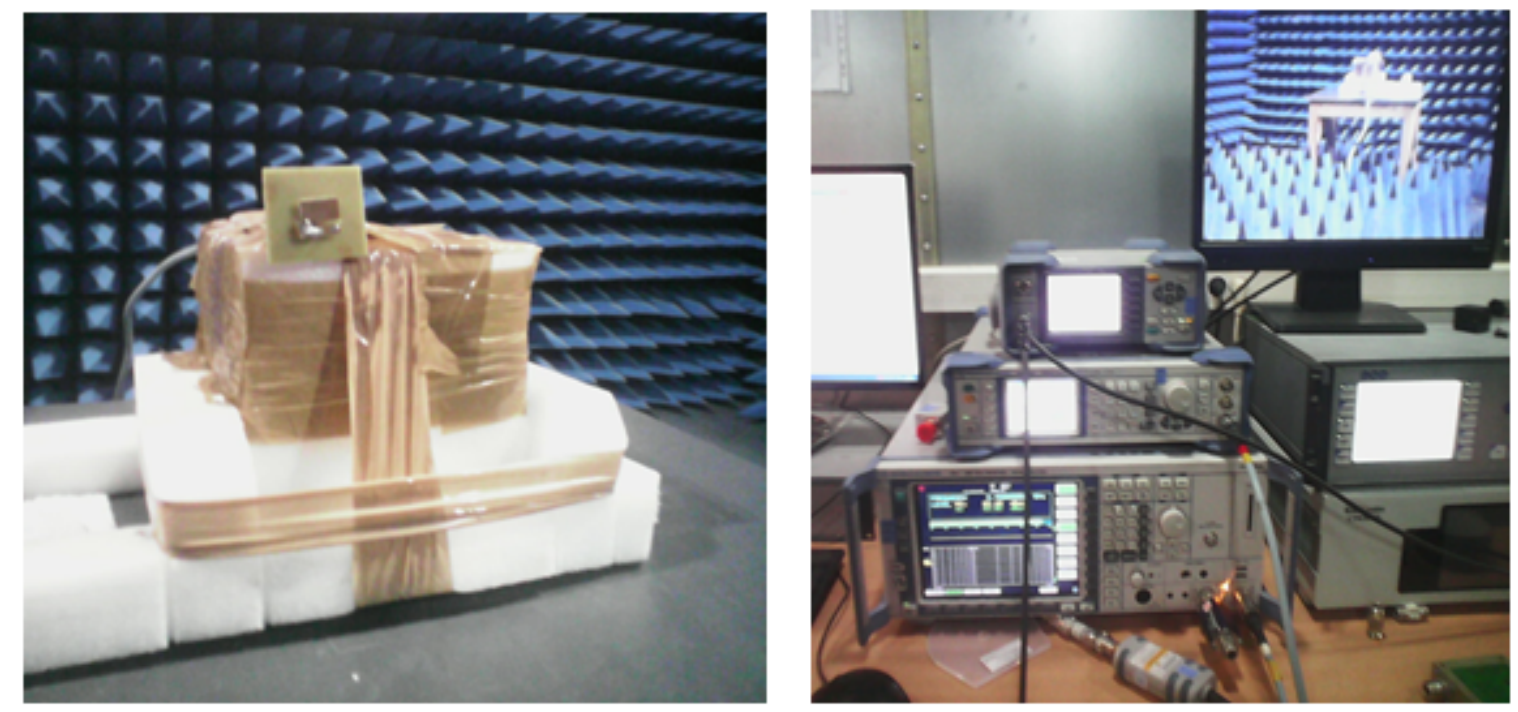

Figure 11

Measurement setup of the PIFA antenna in an anechoic chamber 

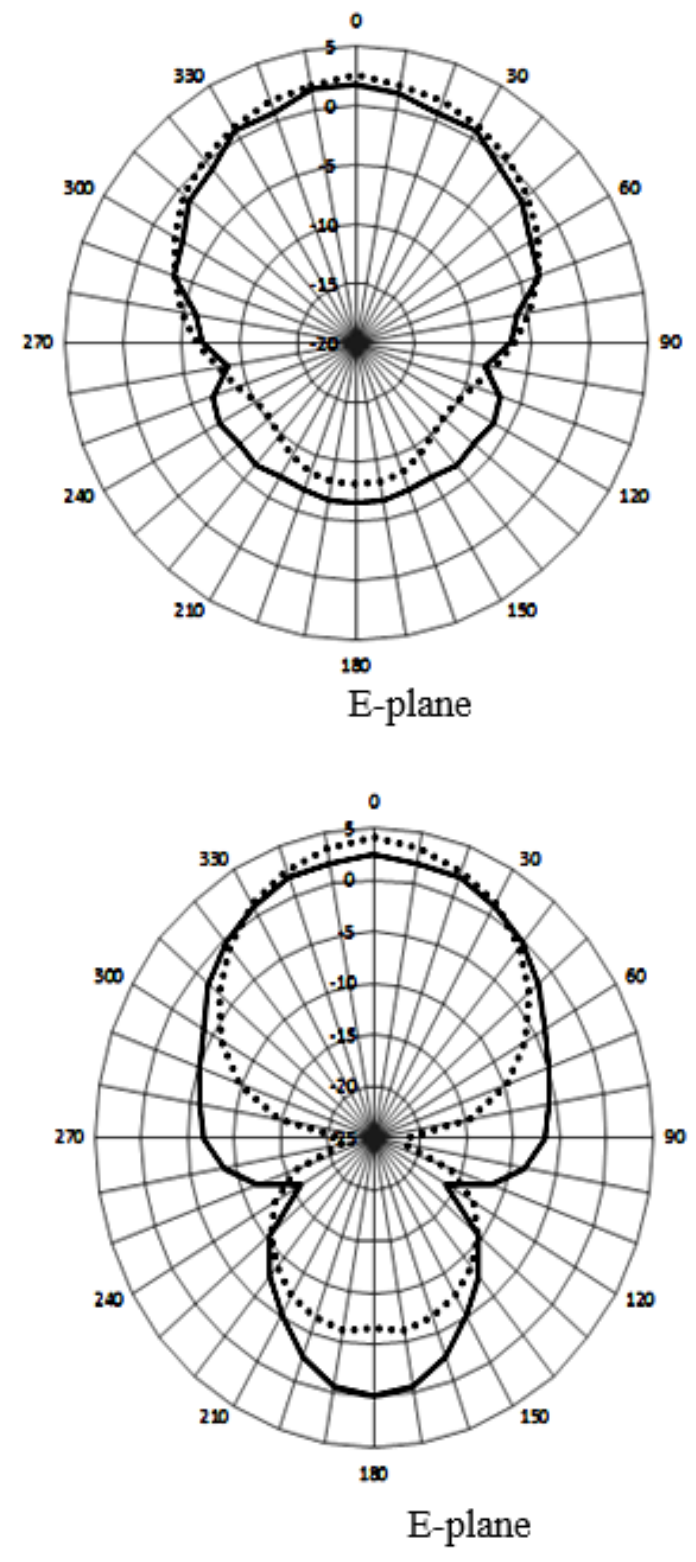

… Simulation

Measurement

(b)

(a)
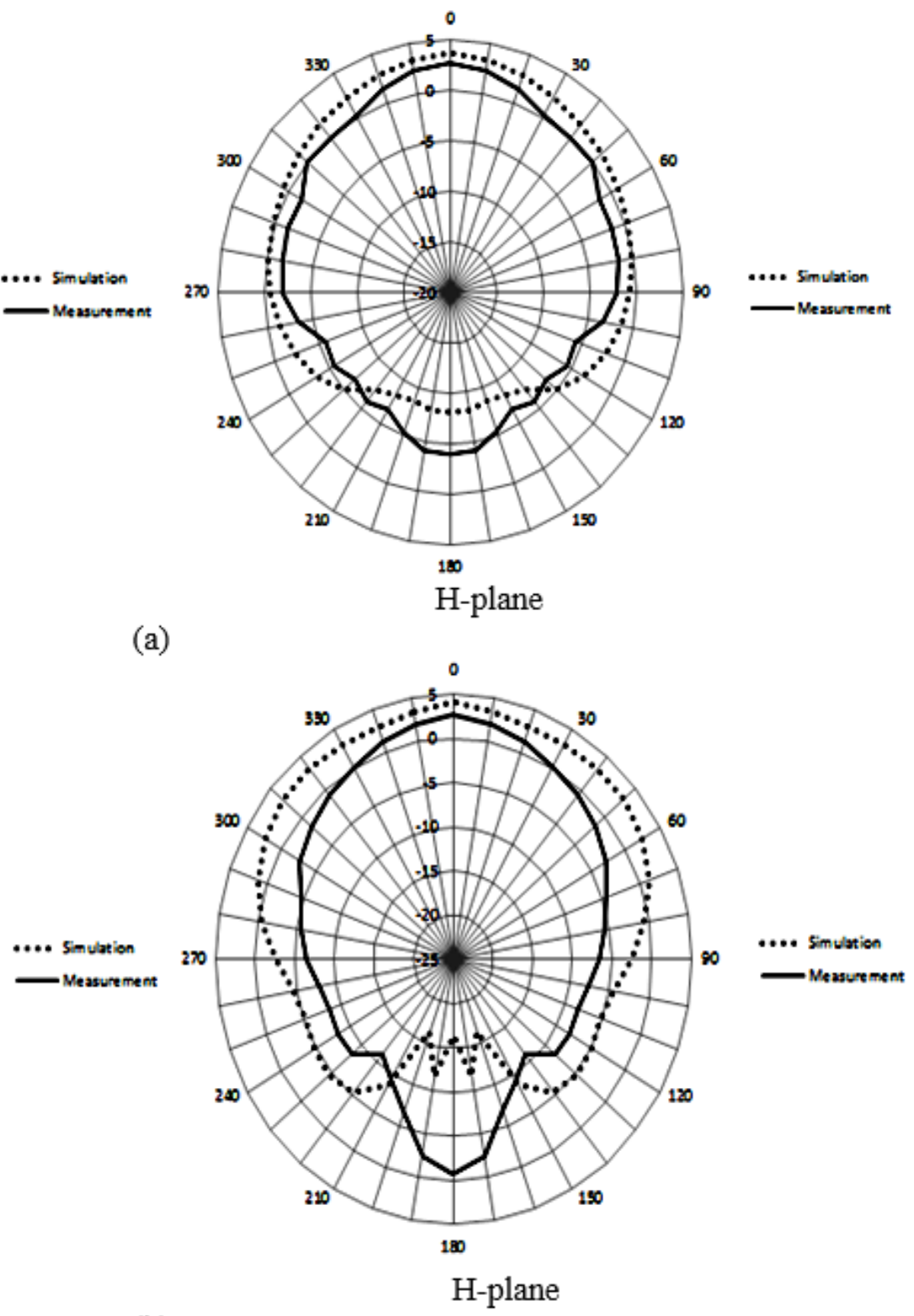

\section{Figure 12}

Simulated and measured radiation pattern at: (a) $2.5 \mathrm{GHz}$, (b) $5.8 \mathrm{GHz}$ 


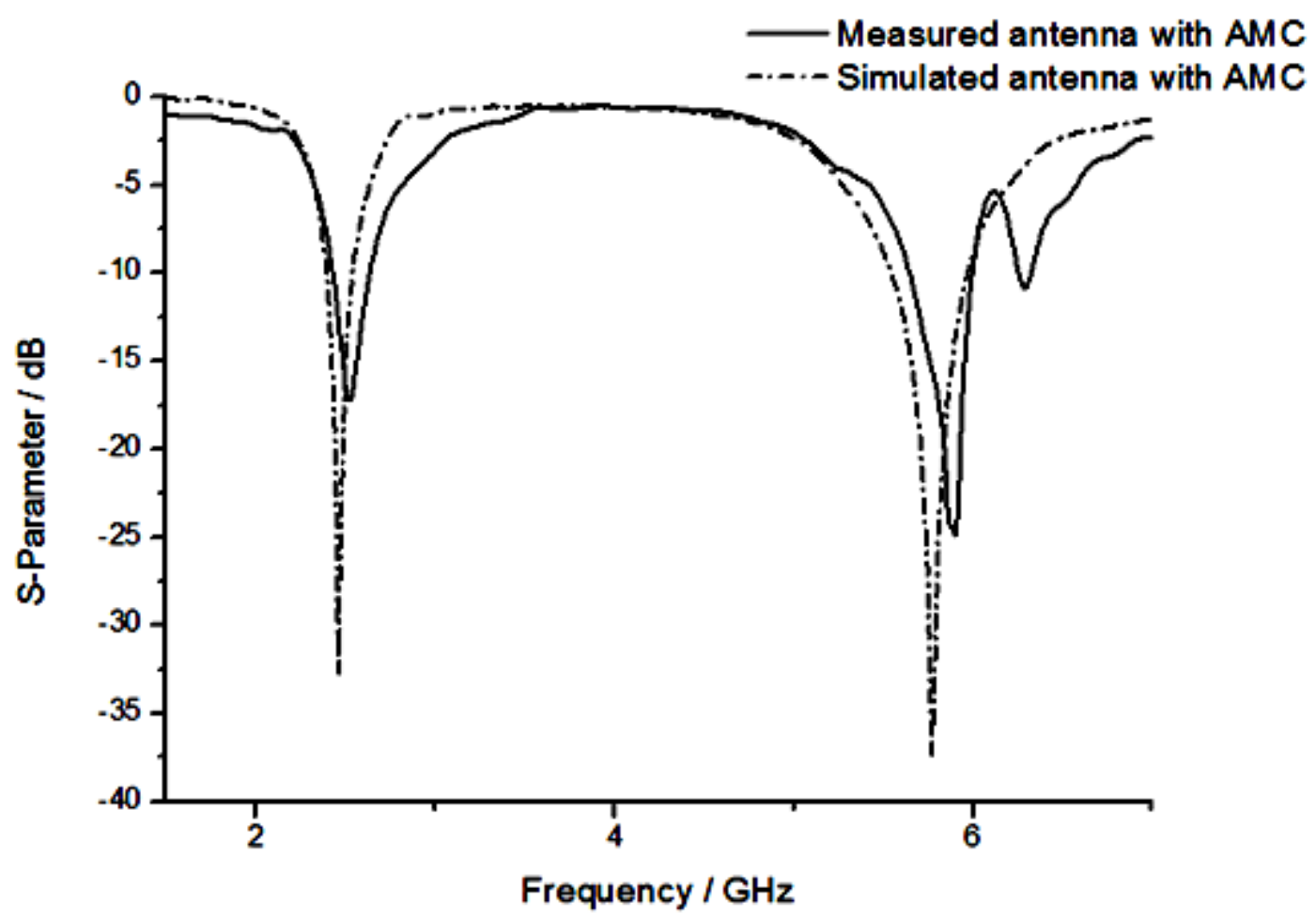

Figure 13

Simulated and measured reflection coefficient of the PIFA antenna with AMC 


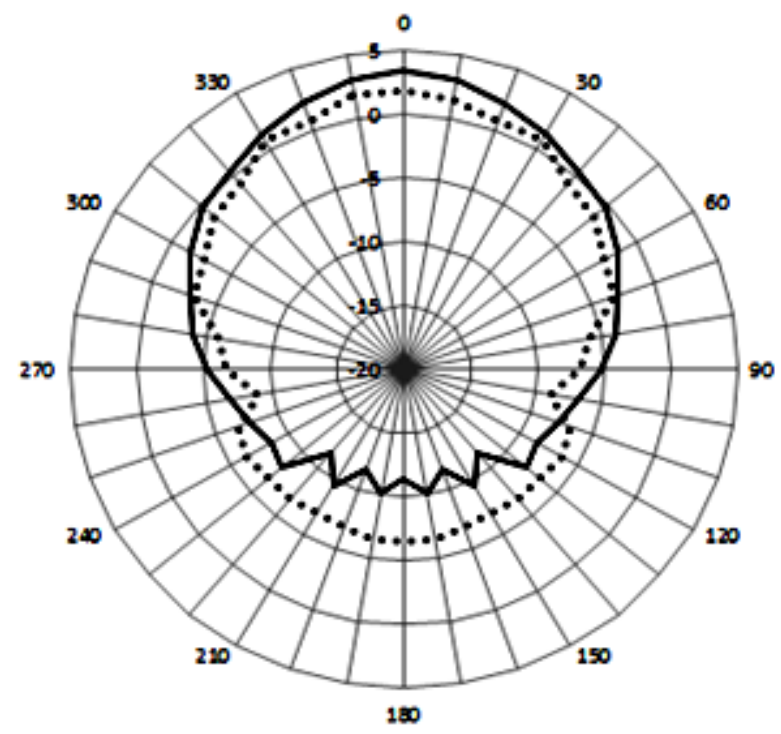

E-plane

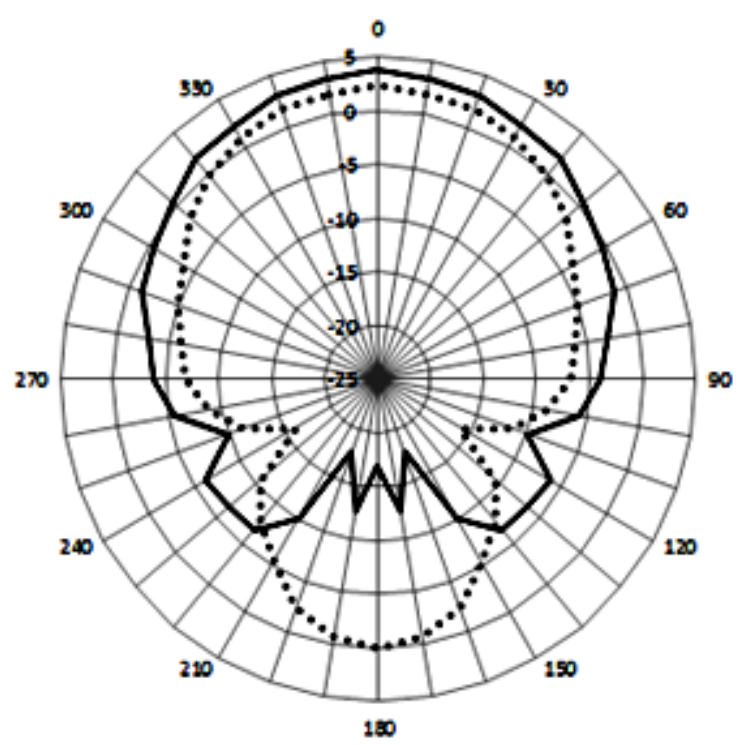

E-plane

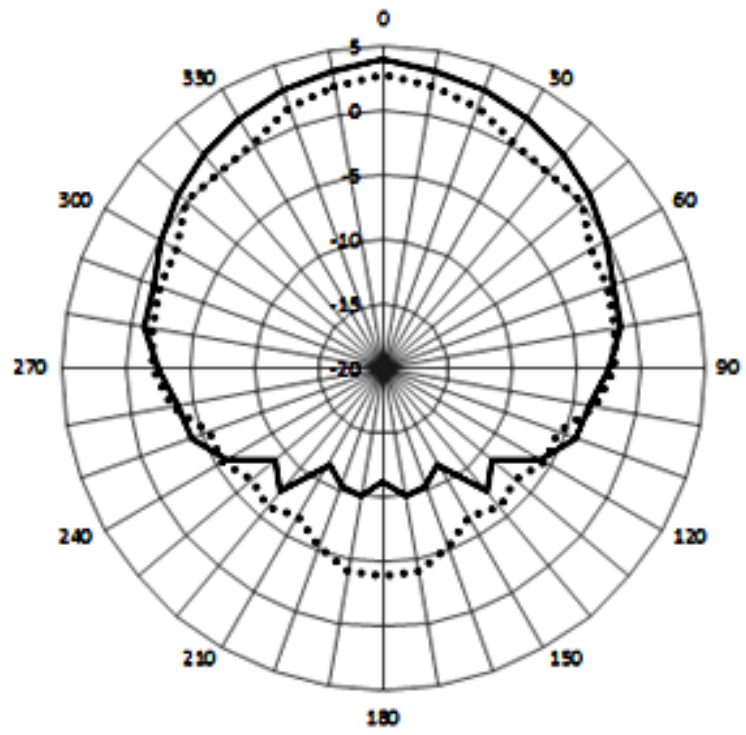

H-plane

(a)

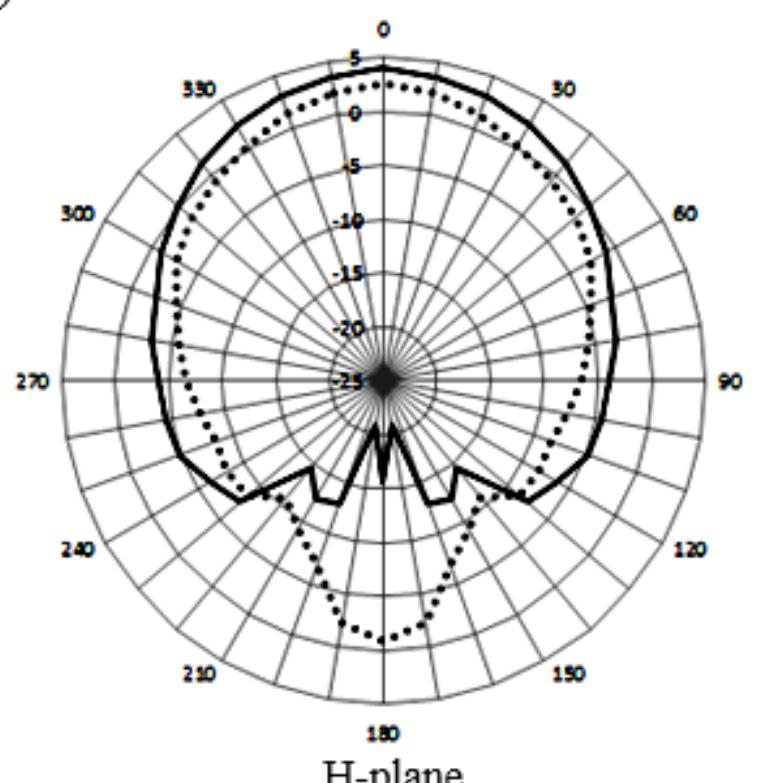

(b)

\section{Figure 14}

Measurement radiation pattern of the PIFA antenna with and without AMC for two planes (E-plane; $\mathrm{H}$ plane) at: (a) $2.5 \mathrm{GHz}$, (b) $5.8 \mathrm{GHz}$ 


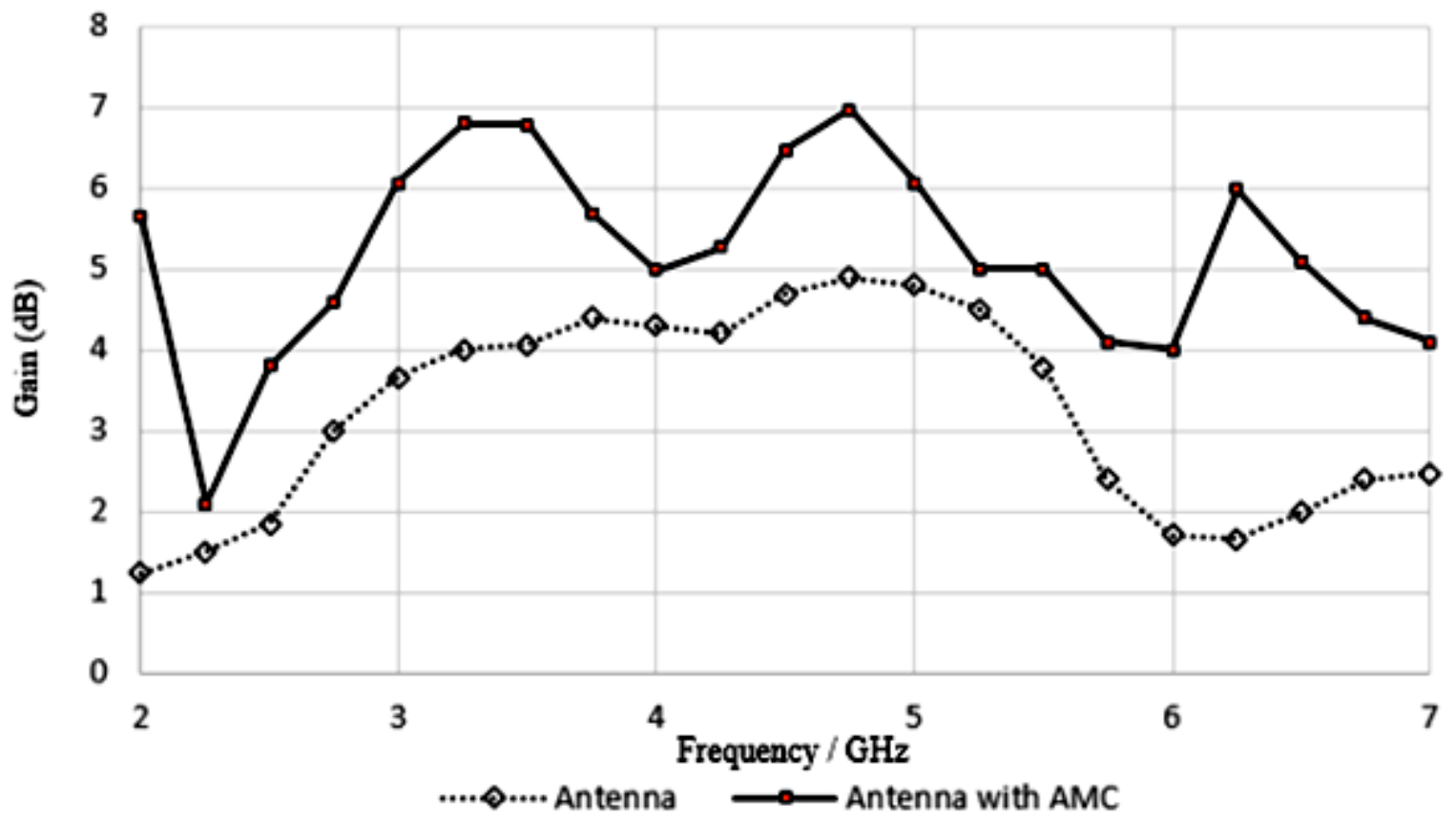

Figure 15

Measured gain of the PIFA antenna with and without AMC

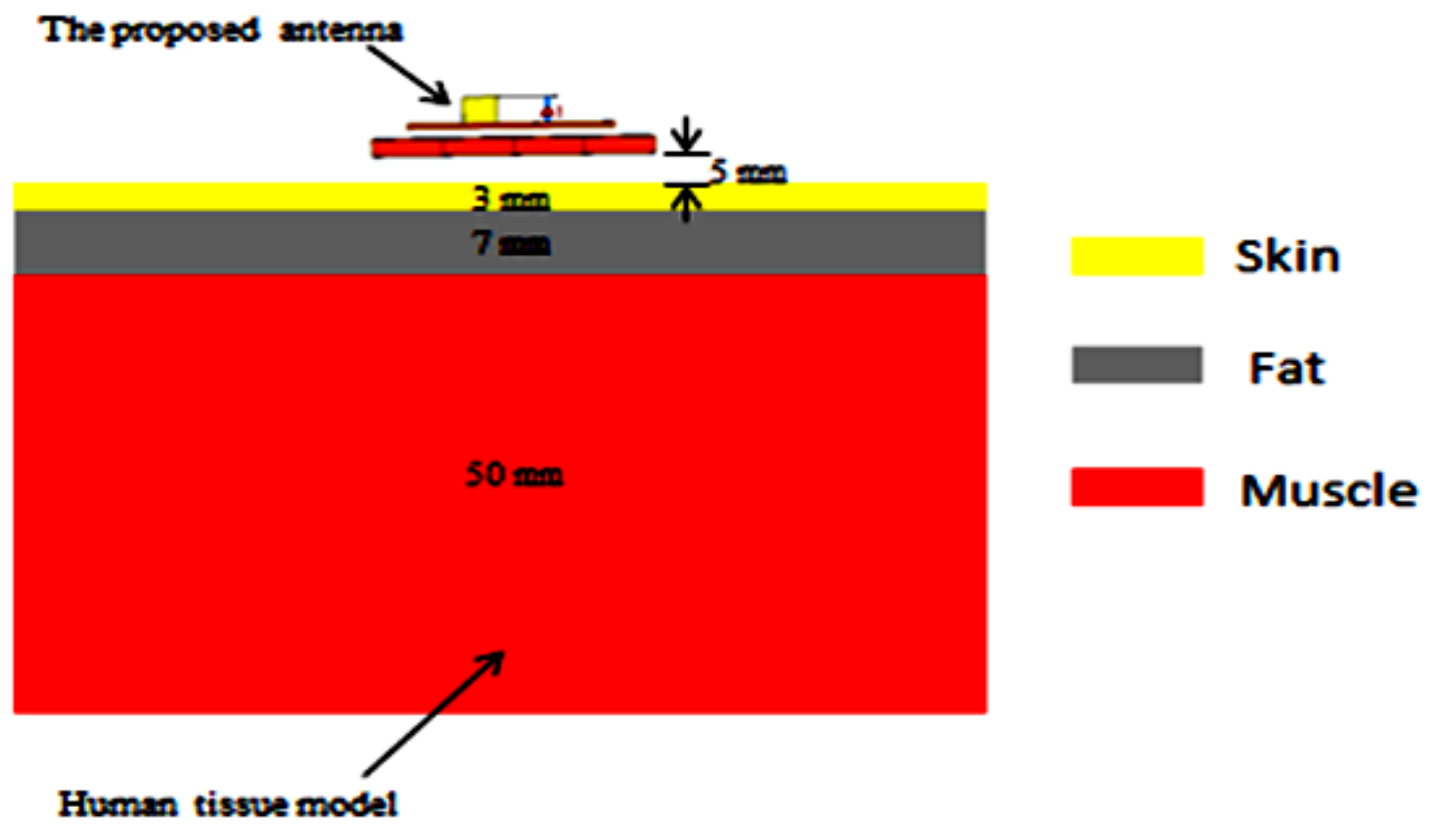

Figure 16

Simulated prototype on three-layer human tissue cubic model 


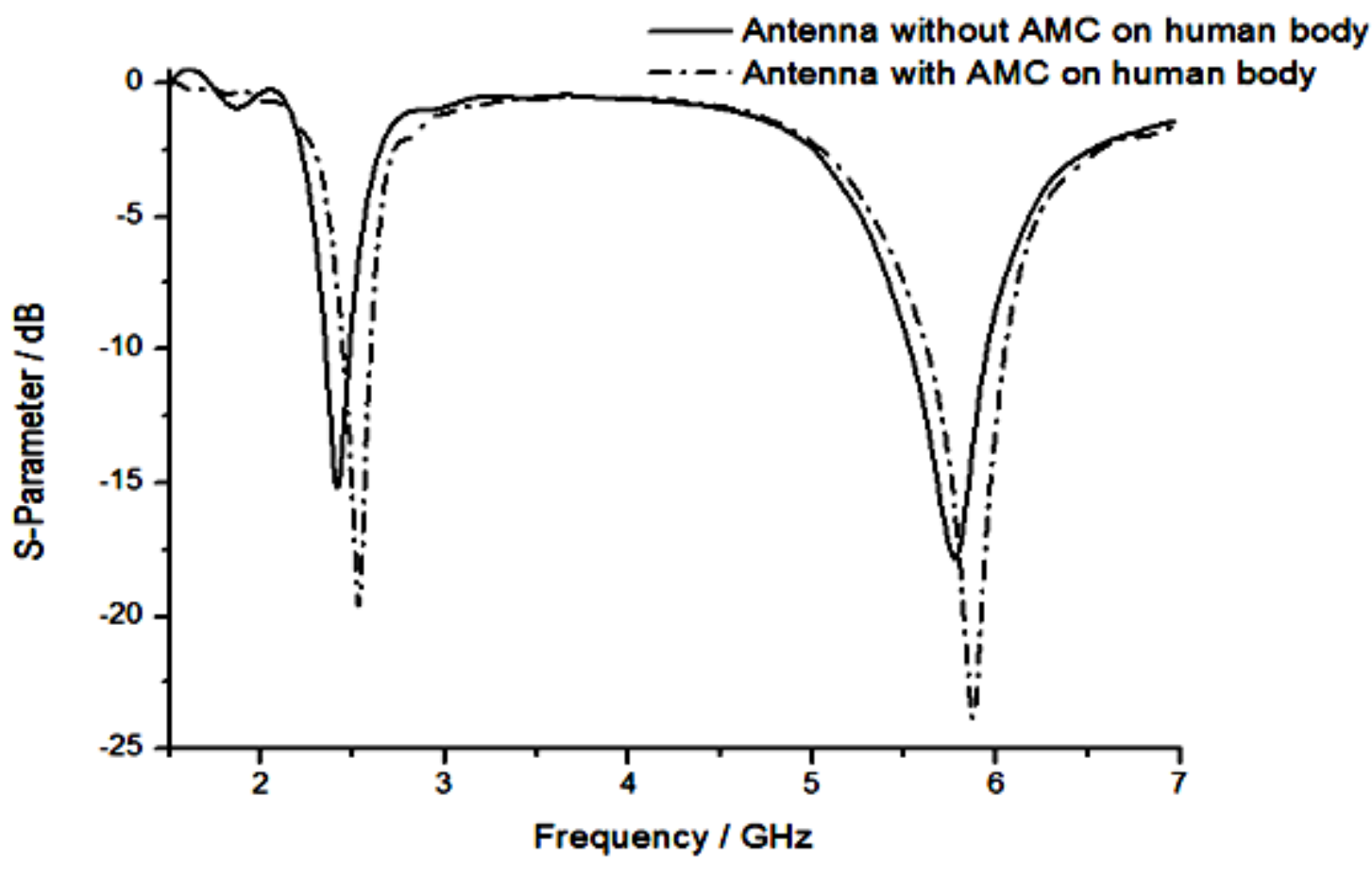

Figure 17

Reflection coefficient with and without AMC in interaction with model 


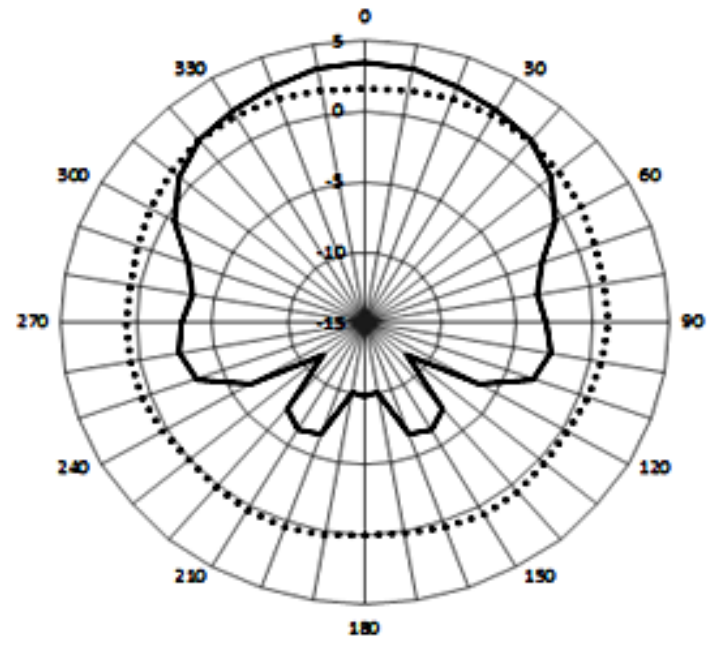

E-plane

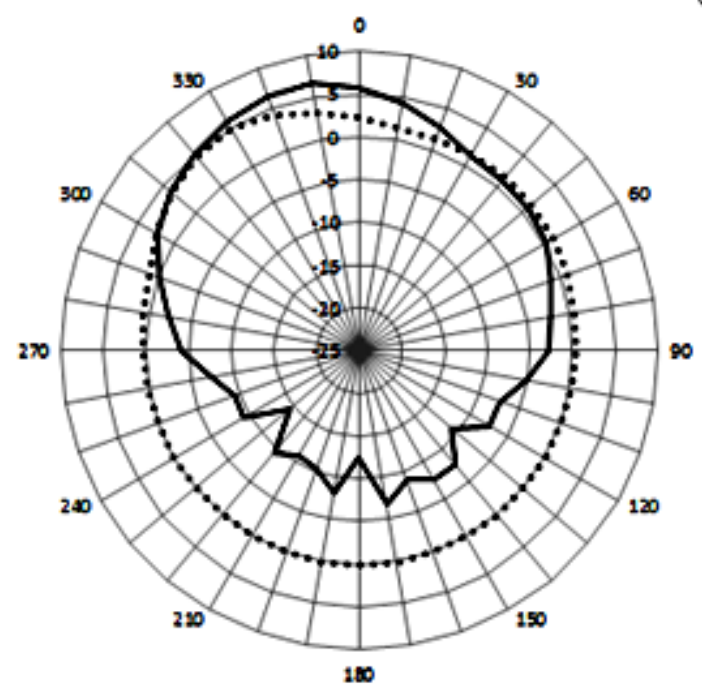

E-plane

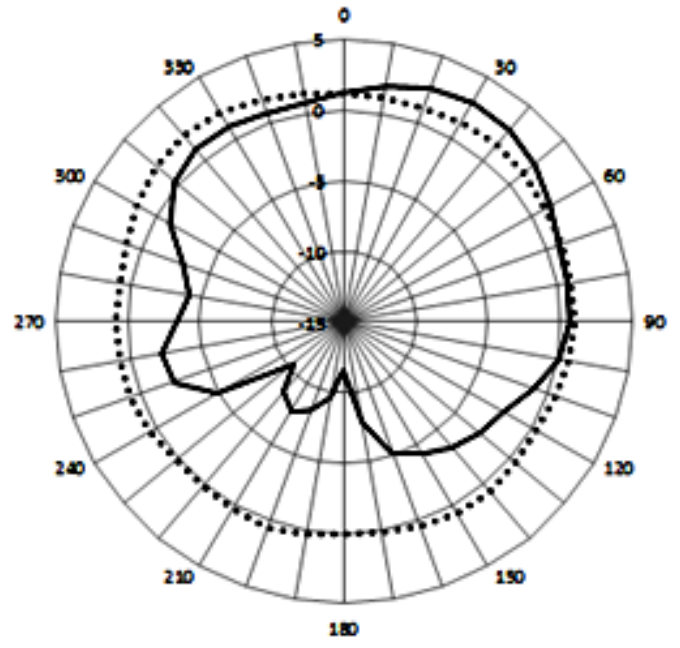

H-plane

(a)

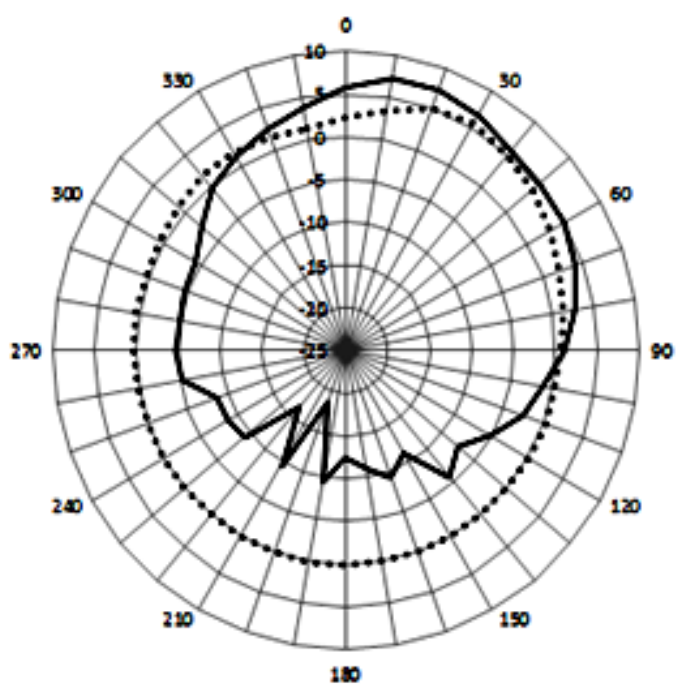

H-plane

(b)

Figure 18

Radiation pattern with and without AMC in interaction with model (a) $2.45 \mathrm{GHz}$, (b) $5.8 \mathrm{GHz}$ 